\title{
Investigating Preschool Teachers' Self-Efficacy in Inclusion Practices in Turkey
}

\author{
Osman Özokcu ${ }^{1}$ \\ ${ }^{1}$ Department of Special Education, Faculty of Education, Inonu University, Malatya, Turkey \\ Correspondence: Osman Özokcu, Faculty of Education, Inonu University, Malatya, Turkey. E-mail: \\ ozokcu@gmail.com
}

Received: April 26, 2018

Accepted: May 30, 2018 Online Published: August 28, 2018

doi:10.5539/ies.v11n9p79

URL: https://doi.org/10.5539/ies.v11n9p79

\begin{abstract}
This study investigated preschool teachers' self-efficacy levels in inclusion practices in terms of teacher-related demographic variables. The study was designed as a descriptive survey study using quantitative data collection tools. The participants were 318 teachers who are working in preschool educational institutions in the province of Malatya, Turkey. The Teacher Efficacy for Inclusive Practice (TEIP) Scale, which was developed by Sharma, Loreman, and Forlin (2012) and whose validity and reliability studies were carried out by Bayar (2015), was used to determine preschool teachers' self-efficacy in inclusive practices. The study found that the preschool teachers scored 4.91 out of six points on the TEIP scale, which measures self-efficacy in inclusion practices. The preschool teachers' age, gender, educational level, and level of interaction with individuals with special needs were not found to affect their scores on the scale significantly; however, their levels of special education training, knowledge of local laws and policies, self-confidence in working with disabled individuals, and experience in working with disabled students were found to affect their scores significantly. The findings of this study were discussed with possible implications for teachers in Turkey.
\end{abstract}

Keywords: inclusive education, preschool education, teacher self-efficacy

\section{Introduction}

In the last twenty-five years, teachers and families have focused their attention on inclusion practices in Turkey. The first laws and practices regarding inclusive education in Turkey were began with the Law for Children Who Need Special Education in 1983 (The Ministry of National Education [MoNE], 1983) and the placement of children with special needs in general classrooms has been accelerated since then (Sucuoğlu, 2004; Sucuoğlu et al., 2014). With the delegated legislation number 573 about special education (MoNE, 1997) which came into force in 1997, and the Special Education Services Regulation (MoNE, 2006), which came into force in 2006, a striking increase in inclusion practices has been experienced. As a requirement of the Special Education Services Regulation, the MoNE asked to place 37-66 month-old children with special education needs in schools where their typically developing peers receive their education. Therefore, there has been a rapid increase in the number of students with special needs in general schools (MoNE, 2006).

In spite of the rapid increase in the number of students with special needs in inclusive environments, problems with providing support and special education services to these students and the teachers who are the most essential element of inclusion have been experienced (Batu \& Kircaali-İftar, 2005; Kargın, 2004; Öztürk-Özgönenli \& Girli, 2016). Studies conducted to determine inclusive preschool teachers' problems have reported that they have problems assessing students with special needs, developing individualized education plans, individualizing teaching, managing classrooms and coping with problem behaviors (Gök \& Erbaş, 2011; Saraç \& Çolak, 2012; Sucuoğlu et al., 2014; Varlıer \& Vuran, 2006). The literature has also reported that preschool teachers need more knowledge in order to meet the needs of their students with special needs and that they do not see themselves as sufficiently capable of teaching them effectively (Akalın, Demir, Sucuoğlu, Bakkaloğlu, \& İşcen, 2014; Batu, 2010; Crane-Mitchell \& Hedge, 2007; Gök \& Erbaş, 2011; Huang \& Diamond, 2009; Odom \& Bailey, 2001; Soodak, Erwin, Winton, Brotherson, Turnbull, \& Hanson, 2002; Sucuoğlu et al., 2014).

Teachers' self-efficacy beliefs are seen as one of the most important factors that affect the success of inclusion practices (Jordan, Schwartz \& McGhie-Richmond, 2009; Paneque \& Barbetta, 2006; Sharma et al., 2012). The 
concept of self-efficacy was first defined by Bandura (1977) as individuals' beliefs regarding their capacity to organize activities and actions that are necessary for them to exhibit a particular performance and carry them out successfully. Bandura's description of self-efficacy belief was adapted for teachers' self-efficacy beliefs and defined as: "teachers' sense or feeling of self-confidence in providing effective education to their students" (Guskey \& Passaro, 1994, p. 628). Tschannen-Moran and Woolfolk-Hoy (2001) defined teachers' self-efficacy as the belief that they will demonstrate behaviors that are necessary to fulfill their roles as teachers successfully. Teachers' perceptions regarding their competencies are accepted as one of the most important factors that affect their teaching practices.

Previous studies have determined that inclusive teachers' levels of self-efficacy perceptions affect their educational activities. Some studies have found a relationship between teachers' high self-efficacy perceptions and being more open to inclusion (Meijer \& Foster, 1988; Sodak \& Podell, 1993a; Soodak \& Podell, 1993b; Soodak, Podell, \& Lehman, 1998). It has been reported that there is a direct relationship with perceived success in teaching and having students with special needs in general classrooms (Brownell \& Pajares, 1999), that children with special needs are able to cope with their authentic behavioural problems much better (Almong \& Shechtman, 2007), and that teachers give priority to students with learning and behavioral problems (Lesyer, 2002). Teachers have also been reported to express positive perspectives on the inclusion of students with special needs (Diken, 2006). Conversely, it has also been reported that teachers with low self-efficacy allocate more time for non-academic work and prevent students from learning by using ineffective teaching methods (Savolainen, Engelbrecht, Nel, \& Malinen, 2011; Sharma et al., 2012).

The services provided for children with special needs during their preschool education are of critical importance for their future success and their integration in society. Therefore, preschool is the most appropriate time to begin a successful inclusion. Teachers' self-efficacy beliefs are seen as one of the most significant factors that affect their teaching practices in inclusive education and their positive attitudes towards students with special needs. Qualitative studies in Turkey have indicated that preschool teachers' knowledge, experience and competencies regarding inclusion are very limited. However, a very limited number of quantitative studies were encountered. This study is important because it determines preschool teachers' self-efficacy in inclusion practices. This study aimed to determine preschool teachers' self-efficacy levels in inclusion practices and to investigate the effects of demographic characteristics on their scores on the Teacher Efficacy Inclusion Practices Scale. This study aimed to answer these research questions:

1) What are the preschool teachers' self-efficacy levels in inclusion practices?

2) Do the preschool teachers' self-efficacy levels differ by teacher-related demographic variables?

\section{Methodology}

\subsection{Model of the Study}

Aiming to describe teachers' self-efficacy in inclusive education, this descriptive study was designed as a survey study (Büyüköztürk, Kılıç-Çakmak, Akgün, Karadeniz, \& Demirel, 2009). This study examines whether preschool teachers' self-efficacy in inclusion practices differs by teacher-related demographic variables.

\subsection{Universe and Sample}

A total of 768 preschool teachers at state preschools and nursery schools in the province of Malatya, Turkey constituted the universe of the study. The participants were selected using the convenience sampling technique. The survey used an appropriate sampling method that was not based on the probability that the participants were selected because of their accessibility (Büyüköztürk et al., 2009). The researcher continues his research by starting with a group of the most accessible samples until the sample size required by the researcher in the appropriate sampling method is reached. The districts in the province of Malatya were taken into consideration in the selection of the participants. This study accessed 318 preschool teachers, which is $41 \%$ of the 768 preschool teachers at state preschools and nursery schools in the province and districts of Malatya. The sampling rate was $90 \%$. Of the participants, 283 were female, and 35 were male.

\subsection{Data Collection Tools}

The Teacher Efficacy for Inclusive Practice (TEIP) scale developed by Sharma, Loreman, and Forlin (2012) to determine pre-service teachers' efficacies in inclusion practices and the Personal Information Form were used to collect the data. The TEIP scale consists of 18 six-point Likert-type items (1-strongly disagree, 2-disagree, 3-partially disagree, 4-partially agree, 5-agree, 6-strongly agree). Scores on the scale range from 18 to 108 . The scale has three sub-scales: Efficacy in use inclusive instruction (EI), Efficacy in managing behavior (EM) and Efficacy in collaboration (EC). High scores on the scale indicate more positive tendencies towards inclusion, less 
anxiety and high self-efficacy. Bayar (2015) adapted the scale into Turkish and conducted its reliability and validity studies. The reliability of the Turkish version was investigated using Cronbach's alpha test, and the internal consistency coefficient was .89 for the overall scale, and $.88, .90$ and .86 for the sub-scales. The Personal Information Form has eight questions about the teachers' age, gender, level of education, level of interaction with disabled individuals, level of special education training, level of knowledge of local laws and policies, level of confidence in working with disabled individuals and level of experience working with disabled students.

\subsection{Data Collection}

Permission to collect the data was obtained from the Ministry of National Education (MoNE) in the fall term of the 2017-2018 academic year, the schools were visited and the scales were administered to the teachers who voluntarily agreed to participate in the study. After eliminating the scales that were incomplete or filled out inappropriately, the data obtained from 318 scales was uploaded to computers.

\subsection{Data Analysis}

SPSS software was used to analyze the data. The arithmetic means and standard deviations of the teachers' scores on the TEIP scale and the three sub-scales were calculated. One-way analysis of variance (ANOVA) and the independent samples t-test were used to investigate whether the teachers' self-efficacy in inclusion practices differed by the variables included in the study. The Tukey multiple comparison test was carried out when the variance was homogenous among the groups and ANOVA analysis yielded a significant $F$ value (Büyüköztürk, 2005).

\section{Results}

Descriptive statistical calculations were made on the data obtained in order to reveal the self-efficacy scores on inclusion practices of the preschool teachers. The lowest and highest scores, arithmetic mean and standard deviation scores from the scale and its sub-dimensions were calculated and the findings are presented in Table 1.

\subsection{Results Regarding the Preschool Teachers'Self-Efficacy Scores in Inclusion Practices}

Table 1. Arithmetic means and standard deviation values of the preschool teachers' self-efficacy scores in inclusion practices

\begin{tabular}{lcccc}
\hline Scale Scores & $\mathrm{X}$ & $\mathrm{Sd}$ & $\mathrm{Min}$ & $\mathrm{Max}$ \\
\hline TEIP Total Score & 4.91 & .61 & 3.00 & 6.00 \\
Inclusive instruction & 4.90 & .67 & 2.50 & 6.00 \\
Collaboration & 4.88 & .66 & 2.67 & 6.00 \\
Managing behavior & 4.94 & .67 & 2.50 & 6.00 \\
\hline
\end{tabular}

The teachers' mean score on the TEIP scale was 4.91. Scores close to five indicate that the teachers agree with the items that measure teacher efficacy. While the teachers scored highest $(X=4.94)$ on the efficacy in managing behavior sub-scale, they scored lowest on the collaboration efficacy sub-scale.

\subsection{The Distribution of the Preschool Teachers'Self-Efficacy Scores Regarding Inclusion Practices According to Teacher-Related Demographic Variables}

The t-test and one-way ANOVA were performed to determine whether the self-efficacy scores on inclusion practices of the classroom teachers differed significantly according to demographic variables.

3.2.1 Evaluation of Self-Efficacy Scores on Inclusion Practices of the Preschool Teachers According to "Gender" Variable

Table 2. The t-test results for the preschool teachers' self-efficacy scores in inclusion practices by gender

\begin{tabular}{ccccccc}
\hline \multirow{2}{*}{ Scale Scores } & \multicolumn{2}{c}{ Female $(\mathrm{N}=283$} & \multicolumn{2}{c}{ Male $(\mathrm{N}=35)$} & \multirow{2}{*}{$\mathrm{t}$} & $\mathrm{p}$ \\
\cline { 2 - 5 } & $\mathrm{X}$ & $\mathrm{Sd}$ & $\mathrm{X}$ & $\mathrm{Sd}$ & & \\
\hline TEIP Total Score & 88.07 & 11.15 & 91.40 & 10.32 & 1.678 & .094 \\
Inclusive instruction & 29.30 & 4.08 & 30.28 & 3.38 & 1.993 & .047 \\
Collaboration & 29.21 & 4.01 & 30.37 & 3.71 & 1.623 & .106 \\
Managing behavior & 29.55 & 3.99 & 30.74 & 4.18 & 1.650 & .100 \\
\hline
\end{tabular}


As Table 2 shows, there was a significant difference by gender on the efficacy in use inclusive instruction sub-scale in favor of the male teachers $[\mathrm{t}(316)=1.993, \mathrm{p}<.05]$. The differences by gender on the other sub-scales were not found to be significant.

3.2.2 Evaluation of Self-Efficacy Scores on Inclusion Practices of the Preschool Teachers According to Educational Level Variable

Table 3. Distribution of the preschool teachers' self-efficacy scores in inclusion practices by level of education

\begin{tabular}{|c|c|c|c|c|c|c|}
\hline \multirow{2}{*}{ Scale Scores } & \multicolumn{2}{|c|}{ Undergraduate $(\mathrm{N}=301)$} & \multicolumn{2}{|c|}{ Graduate $(\mathrm{N}=17)$} & \multirow{2}{*}{$\mathbf{t}$} & \multirow{2}{*}{$\mathbf{p}$} \\
\hline & $\mathbf{X}$ & Sd & $\mathbf{X}$ & Sd & & \\
\hline TEIP Total Score & 88.15 & 11.05 & 93.47 & 10.96 & .071 & .055 \\
\hline Inclusive instruction & 29.30 & 3.99 & 31.29 & 4.10 & .014 & .047 \\
\hline Collaboration & 29.25 & 3.97 & 30.76 & 4.22 & .095 & .131 \\
\hline Managing behavior & 29.58 & 4.04 & 31.41 & 3.39 & .067 & .069 \\
\hline
\end{tabular}

As Table 3 shows, a significant difference was found on the efficacy in use inclusive instruction sub-scale in favor of the teachers with graduate degrees $[\mathrm{t}(316)=.014, \mathrm{p}<.05]$. Differences between the two groups' scores in other sub-scales were not found to be significant.

3.2.3 Evaluation of Self-Efficacy Scores on Inclusion Practices of the Preschool Teachers According To "Interaction with Disabled Individuals" Variable

Table 4. Distribution of the preschool teachers' self-efficacy scores in inclusion practices by level of interaction with disabled people

\begin{tabular}{|c|c|c|c|c|c|c|}
\hline \multirow{2}{*}{ Scale Scores } & \multicolumn{2}{|c|}{ Yes $(\mathrm{N}=199)$} & \multicolumn{2}{|c|}{ No $(\mathrm{N}=119)$} & \multirow{2}{*}{$\mathrm{t}$} & \multirow{2}{*}{$\mathrm{p}$} \\
\hline & $\mathrm{X}$ & $\mathrm{Sd}$ & $\mathrm{X}$ & $\mathrm{Sd}$ & & \\
\hline TEIP Total Score & 89.27 & 10.82 & 87.04 & 11.46 & .326 & .083 \\
\hline Inclusive instruction & 29.68 & 3.77 & 28.94 & 4.38 & 2.296 & .113 \\
\hline Collaboration & 29.72 & 4.02 & 28.68 & 3.87 & .059 & .025 \\
\hline Managing behavior & 29.85 & 3.91 & 29.40 & 4.21 & .002 & .335 \\
\hline
\end{tabular}

As Table 4 shows, the scores of the teachers who had previously interacted with disabled individuals were found to be higher on both the sub-scales and the entire scale. A significant difference was found in the efficacy in collaboration sub-scale in favor of the teachers who had interacted with disabled individuals $[\mathrm{t}(316)=.059$, $\mathrm{p}<.05]$. Differences between the two groups' scores in other sub-scales were not found to be significant.

3.2.4 Evaluation of Self-Efficacy Scores on Inclusion Practices of the Preschool Teachers According to "Ages" Variable

Table 5. Distribution of the preschool teachers' self-efficacy scores in inclusion practices by age

\begin{tabular}{|c|c|c|c|c|c|c|c|c|}
\hline Scale Scores & & & & & & & & \\
\hline \multirow{2}{*}{ Age } & \multicolumn{2}{|c|}{ TEIP Total } & \multicolumn{2}{|l|}{ EI } & \multicolumn{2}{|l|}{ EC } & \multicolumn{2}{|l|}{ EM } \\
\hline & $\mathrm{X}$ & $\mathrm{Sd}$ & $\mathrm{X}$ & $\mathrm{Sd}$ & $\mathrm{X}$ & $\mathrm{Sd}$ & $\mathrm{X}$ & $\mathrm{Sd}$ \\
\hline $25-29(\mathrm{~N}=75)$ & 87.33 & 12.56 & 29.10 & 4.382 & 29.32 & 4.396 & 28,90 & 4.64 \\
\hline $30-34(\mathrm{~N}=165)$ & 88.45 & 10.65 & 29.44 & 3.853 & 29.23 & 3.931 & 29.77 & 3.84 \\
\hline $35-39(\mathrm{~N}=64)$ & 89.65 & 10.06 & 29.60 & 3.688 & 29.78 & 3.839 & 30.26 & 3.51 \\
\hline $40-+(N=) 14$ & 88.57 & 12.95 & 29.71 & 5.566 & 28.71 & 3.406 & 30.14 & 4.62 \\
\hline $\mathrm{F}$ & \multicolumn{2}{|c|}{.503} & \multicolumn{2}{|c|}{.225} & \multicolumn{2}{|c|}{.414} & \multicolumn{2}{|c|}{1.470} \\
\hline $\mathrm{p}$ & \multicolumn{2}{|c|}{.681} & \multicolumn{2}{|c|}{.879} & \multicolumn{2}{|c|}{.743} & \multicolumn{2}{|c|}{.223} \\
\hline
\end{tabular}

$* \mathrm{p}<.05$.

As Table 5 shows, no significant differences were found in the scores on the TEIP total or its sub-scales by age. 
3.2.5 Evaluation of Self-Efficacy Scores on Inclusion Practices of the Preschool Teachers According to "Attending Special Education Courses" Variable

Table 6. Distribution of the preschool teachers' self-efficacy scores in inclusion practices by their level of special education training

\begin{tabular}{|c|c|c|c|c|c|c|c|c|}
\hline \multicolumn{9}{|l|}{ Scale scores } \\
\hline \multirow{2}{*}{ Previous training } & \multicolumn{2}{|l|}{ TEIP total } & \multicolumn{2}{|l|}{ EI } & \multicolumn{2}{|l|}{$\mathrm{EC}$} & \multicolumn{2}{|l|}{ EM } \\
\hline & $\mathrm{X}$ & $\mathrm{Sd}$ & $\mathrm{X}$ & $\mathrm{Sd}$ & $\mathrm{X}$ & $\mathrm{Sd}$ & $\mathrm{X}$ & $\mathrm{Sd}$ \\
\hline Never $(\mathrm{N}=113)$ & 86.40 & 11.51 & 28.69 & 4.517 & 28.57 & 3.95 & 29.14 & 4.14 \\
\hline Some $(\mathrm{N}=149)$ & 88.66 & 10.44 & 29.53 & 3.576 & 29.55 & 3.80 & 29.57 & 3.89 \\
\hline Much $(\mathrm{N}=56)$ & 91.92 & 11.21 & 30.55 & 3.846 & 30.30 & 4.36 & 31.07 & 3.89 \\
\hline Difference & \multicolumn{2}{|c|}{$1-3$} & \multicolumn{2}{|c|}{$1-3$} & \multicolumn{2}{|c|}{$1-3$} & \multicolumn{2}{|c|}{$1-3,2-3$} \\
\hline $\mathrm{F}$ & \multicolumn{2}{|c|}{4.802} & \multicolumn{2}{|c|}{4.225} & \multicolumn{2}{|c|}{3.989} & \multicolumn{2}{|c|}{4.491} \\
\hline $\mathrm{p}$ & \multicolumn{2}{|c|}{.009} & \multicolumn{2}{|c|}{.015} & \multicolumn{2}{|c|}{.019} & \multicolumn{2}{|c|}{.012} \\
\hline
\end{tabular}

As Table 6 shows, a significant difference was found among both the teachers' total TEIP scores and their sub-scale scores by their level of special education training $[\mathrm{F}(2-316)=4.802, \mathrm{p}<.05 ; 4.225, \mathrm{p}<.05 ; 3.989, \mathrm{p}<.05$; $4.491, \mathrm{p}<.05]$.

3.2.6 Evaluation of Self-Efficacy Scores on Inclusion Practices of the Preschool Teachers According to "Level of Knowledge about Local Laws and Policies" Variable

Table 7. Distribution of the preschool teachers' self-efficacy scores in inclusion practices by their level of knowledge about local laws and policies

\begin{tabular}{|c|c|c|c|c|c|c|c|c|}
\hline \multicolumn{9}{|l|}{ Scale Scores } \\
\hline \multirow{2}{*}{$\begin{array}{l}\text { Knowledge of local } \\
\text { policies }\end{array}$} & \multicolumn{2}{|l|}{ TEIP Total } & \multicolumn{2}{|l|}{ EI } & \multicolumn{2}{|l|}{$\mathrm{EC}$} & \multicolumn{2}{|l|}{ EM } \\
\hline & $\mathrm{X}$ & $\mathrm{Sd}$ & $\mathrm{X}$ & $\mathrm{Sd}$ & $\mathrm{X}$ & $\mathrm{Sd}$ & $\mathrm{X}$ & $\mathrm{Sd}$ \\
\hline None $(\mathrm{N}=22)$ & 79.13 & 12.19 & 26.09 & 4.20 & 26.63 & 4.78 & 26.40 & 4.63 \\
\hline Poor $(\mathrm{N}=113)$ & 87.34 & 10.88 & 29.25 & 4.07 & 28.69 & 3.79 & 29.39 & 3.93 \\
\hline Moderate $(\mathrm{N}=122)$ & 89.48 & 8.88 & 29.77 & 3.28 & 29.63 & 3.43 & 30.07 & 3.36 \\
\hline Good $(\mathrm{N}=55)$ & 90.20 & 12.87 & 29.60 & 4.52 & 30.43 & 4.35 & 30.16 & 4.62 \\
\hline Very $\operatorname{good}(\mathrm{N}=6)$ & 105.66 & 2.65 & 35.33 & .816 & 35.50 & .54 & 34.83 & 1.32 \\
\hline Difference & \multicolumn{2}{|c|}{$\begin{array}{c}1-2,1-3,1-4,1-5,2-5,3-5 \\
4-5\end{array}$} & \multicolumn{2}{|c|}{$\begin{array}{c}1-2,1-3,1-4,1-5,2-5 \\
3-5,4-5\end{array}$} & \multicolumn{2}{|c|}{$\begin{array}{c}1-2,1-4,1-5,2-4,2-5 \\
3-1,3-5\end{array}$} & \multicolumn{2}{|c|}{$\begin{array}{c}1-2,1-3,1-4,1-5,2-5 \\
3-5,4-5\end{array}$} \\
\hline $\mathrm{F}$ & \multicolumn{2}{|c|}{10.120} & \multicolumn{2}{|c|}{9.210} & \multicolumn{2}{|c|}{8.811} & \multicolumn{2}{|c|}{7.230} \\
\hline $\mathrm{p}$ & \multicolumn{2}{|c|}{.000} & \multicolumn{2}{|c|}{.000} & \multicolumn{2}{|c|}{.000} & \multicolumn{2}{|c|}{.000} \\
\hline
\end{tabular}

$* \mathrm{p}<.05$.

As Table 7 shows, significant differences were found between both the teachers' total TEIP scores and their sub-scale scores by knowledge of local laws and policies $[\mathrm{F}(2-316)=10.120, \mathrm{p}<.05 ; 9.210, \mathrm{p}<.05 ; 8.811, \mathrm{p}<.05$; $7.230, \mathrm{p}<.05]$.

3.2.7 Evaluation of Self-Efficacy Scores on Inclusion Practices of the Preschool Teachers According to "Confidence Level” Variable 
Table 8. Distribution of the preschool teachers' self-efficacy scores in inclusion practices by their level of confidence in working with disabled individuals

\begin{tabular}{|c|c|c|c|c|c|c|c|c|}
\hline \multicolumn{9}{|l|}{ Scale Scores } \\
\hline \multirow{2}{*}{ Level of confidence } & \multicolumn{2}{|l|}{ TEIP Total } & \multicolumn{2}{|l|}{ EI } & \multicolumn{2}{|l|}{$\mathrm{EC}$} & \multicolumn{2}{|l|}{ EM } \\
\hline & $\mathrm{X}$ & $\mathrm{Sd}$ & $\mathrm{X}$ & $\mathrm{Sd}$ & $\mathrm{X}$ & $\mathrm{Sd}$ & $\mathrm{X}$ & $\mathrm{Sd}$ \\
\hline Very low $(\mathrm{N}=34)$ & 84.29 & 11.76 & 28.14 & 4.31 & 27.61 & 4.37 & 28.52 & 4.25 \\
\hline Low $(\mathrm{N}=69)$ & 86.13 & 10.79 & 28.66 & 3.89 & 28.55 & 3.73 & 28.91 & 4.11 \\
\hline $\operatorname{Mid}(\mathrm{N}=157)$ & 87.60 & 10.43 & 29.19 & 3.94 & 29.07 & 3.73 & 29.33 & 3.82 \\
\hline $\operatorname{High}(\mathrm{N}=45)$ & 94.35 & 9.76 & 31.20 & 3.46 & 31.46 & 3.70 & 31.68 & 3.38 \\
\hline Very high $(\mathrm{N}=13)$ & 101.07 & 7.46 & 33.15 & 2.85 & 33.84 & 2.51 & 34.07 & 2.53 \\
\hline Difference & \multicolumn{2}{|c|}{$\begin{array}{c}1-2,2-4,2-5,3-4,3-5,4-1 \\
5-1\end{array}$} & \multicolumn{2}{|c|}{$1-4,1-5,2-4,2-5,3-4,3-5$} & $\begin{array}{r}1-4 \\
2-4,3\end{array}$ & & \multicolumn{2}{|c|}{$1-4,1-5,2-4,2-5,3-4,3-5$} \\
\hline $\mathrm{F}$ & \multicolumn{2}{|c|}{10.732} & \multicolumn{2}{|c|}{7.096} & \multicolumn{2}{|c|}{1.959} & \multicolumn{2}{|c|}{9.111} \\
\hline $\mathrm{p}$ & \multicolumn{2}{|c|}{.000} & \multicolumn{2}{|c|}{.000} & \multicolumn{2}{|c|}{.000} & \multicolumn{2}{|c|}{.000} \\
\hline
\end{tabular}

$* \mathrm{p}<.05$.

As Table 8 shows, significant differences were found between both the teachers' total TEIP scores and their sub-scale scores by level of confidence in working with disabled individuals $[F(2-316)=10.732, p<.05 ; 7.096$, $\mathrm{p}<.05 ; 1.959, \mathrm{p}<.05 ; 9.111, \mathrm{p}<.05]$.

3.2.8 Evaluation of Self-Efficacy Scores on Inclusion Practices of the Classroom Teachers According to "Working Experience" Variable

Table 9. Distribution of the preschool teachers' self-efficacy scores in inclusion practices by level of experience working with disabled individuals

\begin{tabular}{|c|c|c|c|c|c|c|c|c|}
\hline \multicolumn{9}{|l|}{ Scale Scores } \\
\hline \multirow{2}{*}{ Level experience } & \multicolumn{2}{|l|}{ TEIP Total } & \multicolumn{2}{|l|}{ EI } & \multicolumn{2}{|l|}{ EC } & \multicolumn{2}{|l|}{ EM } \\
\hline & $\mathrm{X}$ & $\mathrm{Sd}$ & $\mathrm{X}$ & $\mathrm{Sd}$ & $\mathrm{X}$ & $\mathrm{Sd}$ & $\mathrm{X}$ & $\mathrm{Sd}$ \\
\hline None $(\mathrm{N}=87)$ & 84.98 & 11.67 & 28.29 & 4.36 & 28.19 & 3.98 & 28.49 & 4.49 \\
\hline Little (N=135) & 87.45 & 10.29 & 29.20 & 3.67 & 28.88 & 3.85 & 29.35 & 3.75 \\
\hline Much $(\mathrm{N}=96)$ & 92.94 & 10.28 & 30.70 & 3.83 & 31.01 & 3.70 & 31.22 & 3.49 \\
\hline Difference & \multicolumn{2}{|c|}{$1-3,2-3$} & \multicolumn{2}{|c|}{$1-3,2-3$} & \multicolumn{2}{|c|}{$1-3,2-3$} & \multicolumn{2}{|c|}{$1-3,2-3$} \\
\hline $\mathrm{F}$ & \multicolumn{2}{|c|}{13.664} & \multicolumn{2}{|c|}{8.919} & \multicolumn{2}{|c|}{13.846} & \multicolumn{2}{|c|}{12.086} \\
\hline $\mathrm{p}$ & \multicolumn{2}{|c|}{.000} & \multicolumn{2}{|c|}{.000} & \multicolumn{2}{|c|}{.000} & \multicolumn{2}{|c|}{.000} \\
\hline
\end{tabular}

As Table 9 shows, significant differences were found among both the teachers' total TEIP scores and their sub-scale scores by level of experience working with disabled individuals $[\mathrm{F}(2-316)=13.664, \mathrm{p}<.05 ; 8.919$, $\mathrm{p}<.05 ; 13.846, \mathrm{p}<.05 ; 12.086, \mathrm{p}<.05]$.

\section{Discussion and Conclusion}

This study was conducted to determine Turkish preschool teachers' self-efficacy levels in inclusion practices and the effects of teacher-related demographic variables on them. The preschool teachers scored 4.91 out of a maximum six points on the TEIP scale, with the highest mean score on the behavior management efficacy in managing behavior sub-scale and the lowest mean score on the efficacy in collaboration sub-scale. The preschool teachers' age, gender, educational level, and level of interaction with individuals with special needs were not found to affect their scores significantly; however, their levels of special education training, knowledge of local laws and policies, confidence in working with disabled individuals and experience working with disabled students were found to affect their scores significantly.

Gender had no significant effect on the teachers' total efficacy in inclusion practices on the sub-scales of efficacy in collaboration and efficacy in managing behavior. This variable only significantly affected the teachers' scores on the efficacy in using inclusive instruction subscale. This result is corroborated by the results of many studies reporting that efficacy beliefs of teachers and pre-service teachers from different cultures and working in various stages and branches do not vary by gender (Aksoy \& Diken, 2009; Gerçek, Yılmaz, Köseoğlu, \& Soran, 2006; 
Kaner, 2010; Milner \& Hoy, 2003; Savran \& Çakıroğlu, 2003; Tschannen-Moran, 2001). However, there are also some studies with contradicting results. While some studies have reported that female teachers have higher efficacy levels than male teachers (Alghazo, 2005; Fives \& Looney, 2002), some reported that male teachers have higher efficacy levels than female teachers (Klassen \& Chiu, 2010; Schwarzer \& Hallum, 2008). The difference in the numbers of female and male participants can be a reason for this study's result since female teachers constituted $89 \%$ of the participants. Preschool teaching is considered a profession more suitable for women in Turkish culture. This difference in the results may be attributed to cultures' different understandings of occupations and gender roles and that perception of efficacy in inclusion practices may have changed in time and removed the differences between the genders. This result also suggests that male teachers are more motivated to show that preschool teaching can be done well not only by female teachers, but also by male teachers.

Similarly, the teachers' level of education had no significant effect on their total efficacy in inclusion practices on the sub-scales of efficacy in collaboration and efficacy in managing behavior. This variable significantly affected the teachers' scores only on the efficacy in using inclusive instruction subscale. However, the mean teaching self-efficacy of the teachers with graduate degrees was higher than the self-efficacy of the teachers with undergraduate degrees. These results are corroborated by the relevant literature, which points out that teachers who received a good education in special education and inclusion and teachers with practical experience have high confidence in their teaching skills and high self-efficacy in teaching (Bradshaw \& Mundia, 2006; Subban \& Sharma, 2006). Traditional teacher education has become ineffective in time due to diversified needs (Scleicher, 2011). The power and effectiveness of general education highly depend on effective teaching and professional teacher education that has continuity. Therefore, the high teaching self-efficacy of the teachers with a graduate degree is an expected result.

The teachers' age had no significant effect either their total scale scores or their scores on the sub-scales. The inclusive self-efficacy of the teachers between the ages of 25-29 was lower than that of the teachers between the ages of 30-34, 35-39 and 40 or more. The literature indicates that teachers' concern about inclusive education diminishes as their age and experience increase (Forlin, Loreman, Sharma, \& Earle, 2009; Shama, Forlin, \& Loreman, 2008). This may stem from the fact that novice teachers might have problems using appropriate teaching strategies to achieve teaching objectives. It also implies that as teachers' age average decreases, their self-efficacy scores also decrease.

The teachers' level of interaction with disabled individuals did not make a significant difference in the teachers' self-efficacy scores on the sub-scales of inclusion efficacy in use inclusive instruction and efficacy in managing behavior, but did so only on the sub-scale of efficacy in collaboration. This result contradicts the results of the studies conducted by Brownlee and Carrinton (2000), and Carroll, Forlin and Jobling (2003). Direct interaction with disabled individuals is a significant predictor of a high teaching efficacy and less concern. However, many of the teachers participated in the study have not directly encountered students with special needs, according to another result of the study. This is a very important result that teacher educators and lawmakers should seriously consider.

A significant difference was found among both the teachers' total scale scores and their scores on all the sub-scales in favor of the teachers who had attended a special education course. Weisel and Dror (2006) indicated that receiving education on inclusion has a significant effect on teachers' positive attitudes and self-efficacy in inclusive education. This result underlines the necessity to include special education and inclusive education courses in the curricula of both pre-service and in-service teacher education programs.

The teachers with a high level of knowledge of local laws and policies had significantly higher total scale and sub-scale scores. This resembles the results of other studies in the literature. Sharma et al. (2008) found that teachers become less concern when they are more knowledgeable about local laws and policies. Ashan, Sharma and Deppeler (2012) claimed that teachers have more perceived teaching self-efficacy as their knowledge of local laws and policies increases. This result calls for the dissemination of practical knowledge of the laws on inclusion across the country and the reorganization of teacher education programs according to these laws.

The difference in the teachers' scores by level of experience working with disabled individuals was significant in favor of the teachers who have confidence in working with disabled individuals and are more experienced with disabled students. In other words, self-confidence and experience working with disabled individuals increased the teachers' inclusion self-efficacy. Therefore, it is an expected result that the teachers with a low confidence in working with disabled individuals have low self-efficacy. The result that the teachers who are more experienced with individuals with special needs have higher teaching self-efficacy than teachers without such experience is corroborated by the results of studies in the literature (Avramidis, Bayliss, \& Burden, 2000). 
This study's results indicated that the preschool teachers' self-efficacy in inclusion practices is quite high and that attending a special education course, knowledge of local laws and policies, confidence in working with disabled individuals and experience working with disabled students were found to affect teacher self-efficacy. These results suggest that the teachers' self-efficacy in inclusion practices stems from more interaction with individuals with special needs, being more knowledgeable about local laws and policies, and teacher experience. One of the most important indicators of effective teaching is the quality of the teaching process. For this reason, conducting regular activities to improve teachers' knowledge and skills regarding inclusion in the in-service training provided by MoNE is thought to strengthen teachers' self-efficacy beliefs. Educational faculties should include theoretical courses as well as student-teaching courses that increase students' interaction and experience with students with special needs in their teacher education programs in order to train teachers with high self-efficacy beliefs. In addition, the differences of the results of this study with the results of other studies in the literature regarding the effect of teacher-related demographic variables on teachers' self-efficacy in inclusion practices should be investigated by further in-depth qualitative studies to obtain more consistent and richer data results.

\section{References}

Akalın, S., Demir, Ş., Sucuoğlu, B., Bakkaloğlu, H., \& İşcen, F. (2014). The needs of inclusive preschool teachers about inclusive practices. Eurasian Journal of Educational Research, 54, 39-60. https://doi.org/10.14689/ejer.2014.54.3

Aksoy, V., \& Diken, İ. (2009). Rehber Öğretmenlerin Özel eğitimde Psikolojik Danışma ve Rehberliğe ilişkin Öz Yeterlik Algılarının incelenmesi [Examining school counselors' sense of selfefficacy regarding psychological consultation and counseling in special education]. İlkögretim Online [Elemantary Education Online], 8(3), 709-719.

Alghazo, E. M. (2005). Special education teachers perceptions toward effective instructional practices in the United Arab Emirates (UAE). Teacher Education and Special Education, 28, 221-229. https://doi.org/10.1177/088840640502800408

Almog, O., \& Shechtman, Z. (2007). Teachers' democratic and efficacy beliefs and styles of coping with behavioural problems of pupils with special needs. European Journal of Special Needs Education, 22(2), 115-129. https://doi.org/10.1080/08856250701267774

Ashan, M., Sharma, U., \& Deppeler, J. (2012). Challenges to prepare pre-service teachers for inclusive education in Bangladesh: Beliefs of higher educational institutional heads. Asia Pacific Journal of Education, 32(2), 241-257. https://doi.org/10.1080/02188791.2012.655372

Avramidis, E., Bayliss, P., \& Burden, R. (2000). A survey into mainstream teachers' attitudes towards the Inclusion of children with special educational needs in the ordinary school one local education authority. Educational Psychology, 20(2), 191-211. https://doi.org/10.1080/713663717

Bandura, A. (1977). Self-efficacy: Toward a unifying theory of behavioral change. Psychological Review, 84, 191-215. https://doi.org/10.1037/0033-295X.84.2.191

Batu, E. S., \& Kırcaali-İftar, G. (2005). Kaynaştırma [Mainstreaming]. Ankara: KÖK Yayıncılık.

Batu, S. (2010). Factors for the success of early childhood inclusion \& related studies. International Journal of Early Childhood Special Education (INT-JECSE), 2(1), 57-71.

Bayar, A. (2015). The Adaptation of the Teacher Efficacy for Inclusive Practice in Turkish: The validity and reliability study in inclusion education. Ahi Evran University Kırşehir Education Faculty Journal, 16(3), 71-85.

Bradshaw, L., \& Mundia, L. (2006). Attitudes and concerns about inclusive education: Bruneian inservice and preservice teachers. International Journal of Special Education, 21(1), 35-41.

Brownell, M. T., \& Pajares, F. (1999). Teacher efficacy and perceived student success in mainstreaming students with learning and behavior problems. Teacher Education and Special Education, 22, 154-163. https://doi.org/10.1177/088840649902200303

Brownlee, J., \& Carrington, S. (2000). Opportunities for authentic experience and reflection: a teaching programme designed to change attitudes towards disability for pre-service teachers. Support for Learning, 15(3), 99-105. https://doi.org/10.1111/1467-9604.00157

Büyüköztürk, Ş. (2005). ). Sosyal Bilimler için veri analizi el kitabı [Statistic for social sciences]. Ankara: Pegem 
A Yayıncilik

Büyüköztürk, Ş., Kılıç, E. K., Akgün, Ö. E. Karadeniz, Ş., \& Demirel, F. (2008). Bilimsel Araştırma Yöntemleri [Scientific research methods]. Ankara: Pegem Akademi Yayınları.

Carroll, A., Forlin, C., \& Jobling, A. (2003). The impact of teacher training in special education on the attitudes of Australian preservice general educators towards people with disabilities. Teacher Education Quarterly, 30(3), 65-79.

Crane-Mitchel, L., \& Hedge, A. V. (2007). Belief and practices of in-service preschool teachers in inclusive settings: Implications for personnel preparation. Journal of Early Childhood Teacher Education, 28(4), 353-366. https://doi.org/10.1080/10901020701686617

Diken, İ. (2006). Preservice teachers' efficacy and opinions toward inclusion of students with mental retardation. Eurasian Journal of Educational Research, 23, 72-81.

Fives, H., \& Looney, L. (2002). Efficacy beliefs of college instructors. Draft, 5, 12.

Forlin, C. Cedillo, I. G., \& Romero-Contreras, S. (2010). Inclusion in Mexico: Ensuring supportive attitudes by newly graduate teachers. International Journal of Inclusive Education, 14(7), 723-739. https://doi.org/10.1080/13603111003778569

Forlin, C., Loreman, T., Sharma, U., \& Earle, C. (2009). Demographic differences in changing pre-service teachers' attitudes, sentiments and concerns about inclusive education. International Journal of Inclusive Education, 13(2), 195-209. https://doi.org/10.1080/13603110701365356

Gerçek, C., \& Yılmaz, M., Köseoğlu, P., \& Soran, H. (2006). Biyoloji eğitimi öğretmen adaylarının öğretiminde öz-yeterlilik inançları [Preservice science teachers self efficacy beliefs]. Ankara Üniversitesi Ĕ̈itim Bilimleri Fakültesi Dergisi [Journal of Faculty of Educational Sciences], 39(1), 57-73.

Gök, G., \& Erbaş, D. (2011). Okul öncesi eğitimi öğretmenlerinin kaynaştırmaya ilişkin görüşleri ve önerileri [Early childhood teachers' opinions about and suggestions for inclusion programs]. International Journal of Early Childhood Special Education, 3(1), 66-87.

Guskey, T. R., \& Passaro, P. D. (1994). Teacher efficacy: a study of construct dimensions. American Educational Research Journal, 31, 627-643. https://doi.org/10.3102/00028312031003627

Huang, H. H., \& Diamond, K. E. (2009). Early childhood teachers' ideas about including children with disabilities in programs designed for typically developing children. International Journal of Disability, Development and Education, 56(2), 169-182. https://doi.org/10.1080/10349120902868632

Jordan, A., Schwartz, E., \& McGhie-Richmond, D. (2009). Preparing teachers for inclusive classrooms. Teaching and Teacher Education, 25, 535-542. https://doi.org/10.1016/j.tate.2009.02.010

Kaner, S. (2010). Özel gereksinimli olan ve olmayan öğrencilerin öğretmenlerinin özyetkinlik inançları. [Examining teachers' self-efficacy beliefs of students with and without special needs] Ankara Üniversitesi Eğitim Bilimleri Fakültesi Dergisi [Journal of Faculty of Educational Sciences], 43(1), 193-217.

Kargın, T. (2004). Kaynaştırma: Tanımı, gelişimi ve ilkeleri [ Inclusion: definition, history and principles]. Özel Eğitim Dergisi [Special Education Journal], 5(2), 1-13.

Klassen, R., \& Chiu, M. M. (2010). Effects of teachers' self-efficacy and job satisfaction: teacher gender, years of experience, and job stress. Journal of Educational Psychology, 102, 741-756. https://doi.org/10.1037/a0019237

Leyser Y. (2002). Choices of instructional practices and efficacy beliefs of Israeli general and special educators: A cross-cultural research initiative. Teacher Education and Special Education: The Journal of the Teacher Education Division of the Council for Exceptional Children, 2,154.

Meijer, C., \& Foster, S. (1988). The effect of teacher self-efficacy on referral chance. Journal of Special Education, 22, 378-385. https://doi.org/10.1177/002246698802200309

Milner, H. R., \& Hoy, A. W. (2003). A case study of an African American teacher's self-efficacy, sterotype threat, and persistence. Teaching And Teacher Education, 19, 263-276. https://doi.org/10.1016/S0742-051X(02)00099-9

MoNE, (2006). Özel Eğitim Hizmetleri Yönetmeliği [Regulations on special education services]. Retrieved from http://mevzuat.meb.gov.tr/html/26184_0.html

MoNE. (1997). Özel Eğitim Hakkında Kanun Hükmünde Kararname [Special education law]. Retrieved from 
http://www.mevzuat.gov.tr/MevzuatMetin/4.5.573.pdf

Moran, T., \& Hoy, A.W. (2002). The influence of resources and support on teachers' efficacy beliefs. American Educational Reserach Association, 13, 1-8.

Odom, S. L., \& Bailey, D. B. (2001). Inclusive preschool programs: Classroom ecology and child outcomes. In M. J. Guralnick (Ed.), Early childhood inclusion: Focus on change (pp. 253-276). Baltimore, MD: Paul H. Brookes Publishing Co., Inc.

Öztürk Özgönenel, S. Ö., \& Girli, A. (2016). Otizmli kaynaştırma öğrencilerinin sınıflarında akran ilişkilerinin geliştirilmesine yönelik eğitim programının etkililiğinin incelenmesi [The Examination of an education program to improve peer relationships of the autistic children integrated in classrooms]. Ilkögrretim Online [Elemantary Education Online], 15(1), 286-298.

Paneque, O. M., \& Barbetta, P. M. (2006). A study of teacher efficacy of special education teachers of English language learners with disabilities. Bilingual Research Journal, 30(1), 171-193. https://doi.org/10.1080/15235882.2006.10162871

Saraç, T., \& Çolak, A. (2012). Kaynaştırma uygulamaları sürecinde ilköğretim sınıf öğretmenlerinin karşılaştıkları sorunlara ilişkin görüş ve önerileri [Elementary school teachers' views and suggestions regarding the problems encountered in the process of inclusive applications]. Mersin Üniversitesi Ĕgitim Fakültesi Dergisi, [Mersin University Journal of the Faculty of Education ], 8(1), 13-28.

Savolainen, H., Engelbrecht, P., Nel, M., \& Malinen, O. P. (2011) Understanding teachers' attitudes and self-efficacy in inclusive education: implications for pre-service and in-service teacher education. European Journal of Special Needs Education, 27(1), 51-68. https://doi.org/10.1080/08856257.2011.613603

Savran, A., \& Çakıroğlu, J. (2003). Differences between elemantary and secondary preservice scince teacher's perceived efficacy belies and their classroom management beliefs. The Turkish Online Journal of Educational Technology, 2(4), 15-20.

Schleicher, A. (2011). Lessons from the world on effective teaching and learning environments. Journal of Teacher Education, 62(2), 202-221. https://doi.org/10.1177/0022487110386966

Schwarzer, R. and Hallum, S. (2008). Perceived Teacher Self-Efficacy as a Predictor of Job Stress and Burnout Mediation Analyses. Applied Psychology, 57, 152-171. https://doi.org/10.1111/j.1464-0597.2008.00359.x

Sharma, U., Forlin, C. \& Loreman, T. (2008) Impact of training on pre-service teachers' attitudes and concerns about inclusive education and sentiments about persons with disabilities. Disability and Society, 23, 773-785. https://doi.org/10.1080/09687590802469271

Sharma, U., Loreman, T., \& Forlin, C. (2012). Measuring teacher efficacy to implement inclusive practices. Journal of Research in Special Educational Needs, 12(1), 12-21. https://doi.org/10.1111/j.1471-3802.2011.01200.x

Soodak, L. C., \& Podell, D. M. (1993a). Teacher efficacy and bias in special education referrals. Journal of Educational Research, 86(4), 247-253. https://doi.org/10.1080/00220671.1993.9941836

Soodak, L. C., \& Podell, D. M. (1993b). Teacher efficacy and student problem as factors in special education referral. Journal of Special Education, 27, 66-81. https://doi.org/10.1177/002246699302700105

Soodak, L. C., Erwin, J. E., Winton, P., Brotherson, M. J., Turnbull, A. P., \& Hanson, M. J. (2002). Implementing inclusive early childhood education: A call for Professional empowerment. Topics in Early Childhood Special Education, 22(2), 91-102. https://doi.org/10.1177/02711214020220020401

Soodak, L. C., Podell, D. M., \& Lehman, L. R. (1998). Teacher, student, and school attributes as predictors of teachers' responses to inclusion. Journal of Special Education, 31, 480-497. https://doi.org/10.1177/002246699803100405

Subban, P., \& Sharma, U. (2006). Primary school teachers' perceptions of inclusive education in Victoria, Australia. International Journal of Special Education, 21(1), 42-52.

Sucuoğlu, B. (2004). Türkiye'de Kaynaştırma Uygulamaları: Yayınlar/Araştırmalar (1980-2005) [Implementation of inclusion in Turkey: Publications/research]. Özel Eğitim Dergisi [Special Education Journal], 5(2), 15-23.

Sucuoğlu, B., Bakkaloğlu, H., İşcen-Karasu, F., Demir, Ş., \& Akalın, S. (2014). Okul öncesi öğretmenlerinin kaynaştırmaya ilişkin bilgi düzeyleri. [Preschool teachers' knowledge levels about inclusion] Kuram ve 
Uygulamada Eğitim Bilimleri [Educational Sciences: Theory \& Practice], 14(4), 1467-1485.

Tschannen-Moran, M., \& Woolfolk-Hoy, A. (2001). Teacher efficacy: Capturing and elusive construct. Teaching and Teacher Education, 17, 783-805. https://doi.org/10.1016/S0742-051X(01)00036-1

Varlıer, G., \& Vuran, S. (2006). The views of preschool teachers about integration. Educational Sciences: Theory and Practice, 6(2), 578-585.

Weisel, A., \& Dror, O. (2006). School climate, sense of efficacy and Israeli teachers' attitudes toward inclusion of student with special needs' Education, Citizenship and Social Justice, 1(2), 157-174. https://doi.org/10.1177/1746197906064677

\section{Copyrights}

Copyright for this article is retained by the author(s), with first publication rights granted to the journal.

This is an open-access article distributed under the terms and conditions of the Creative Commons Attribution license (http://creativecommons.org/licenses/by/4.0/). 